\title{
Pharmacokinetic Profile of Nimesulide in Bovine Calves
}

\author{
Lombodar Mahapatra', Gyana R. sahoo², Monoj K. Panda ${ }^{3}$, Subas ch. Parija1* \\ 'Department of Pharmacology and Toxicology, College of Veterinary Sciences \\ and Animal Husbandry, Orissa University of Agriculture and Technology, Bhubaneswar-751003 \\ ${ }^{2}$ Department of Biochemistry, College of Veterinary Sciences and Animal Husbandry, \\ Orissa University of Agriculture and Technology, Bhubaneswar-751003 \\ ${ }^{3}$ Central Laboratory, Orissa University of Agriculture and Technology, Bhubaneswar-751003
}

\begin{abstract}
The aim of the present study was to investigate pharmacokinetic profile and bioavailability of cyclooxygenase (COX)-2 selective nonsteroidal anti-infalmmatory drug nimesulide in bovine male calves after intravenous (i.v.) and intramuscular (i.m.) administration at a dose of $4.5 \mathrm{mg} /$ $\mathrm{kg}$ BW. Blood samples were collected by jugular venipuncture at predetermined times following drug administration. Nimesulide in the plasma was assayed by using a validated HPTLC method. Plasma concentration-time data were subjected to compartmental analysis and pharmacokinetic parameters for nimesulide after i.v. and i.m. administration were calculated according to two and onecompartment open models, respectively. Following i.v. administration, a rapid distribution phase was followed by slower elimination phase. The half-lives during distribution phase $\left(\mathrm{t}_{1 / 2 \alpha}\right)$ and terminal elimination phase $\left(\mathrm{t}_{1 / 2 \beta}\right)$ were $0.15 \pm 0.005 \mathrm{~h}$ and $9.02 \pm 0.06 \mathrm{~h}$, respectively. The steady-state volume of distribution $\left(\mathrm{v}_{\mathrm{d}(\mathrm{ss})}\right)$, total body clearance $\left(\mathrm{cl}_{\mathrm{B}}\right)$ and mean residence time (MRT) of nimesulide were $0.22 \pm 0.02 \mathrm{~L} / \mathrm{h} / \mathrm{kg}, 0.02 \pm 0.001$ and $11.23 \pm 0.04 \mathrm{~h}$, respectively. After i.m administration, maximum plasma concentration $\left(\mathrm{c}_{\max }\right)$ of nimesulide was $35.84 \pm 3.04 \mu \mathrm{g} /$ $\mathrm{mL}$ attained at $4.0 \pm 0.19 \mathrm{~h}\left(\mathrm{t}_{\max }\right)$. Plasma drug levels were not detectable upto $72 \mathrm{~h}$. Similarly the $\mathrm{t}_{1 / 2 \beta}(20.08 \pm 0.79 \mathrm{~h})$ MRT $(13.76 \pm 0.09 \mathrm{~h})$ of nimesulide after i.m. administration were significantly longer than the i.v administration. The bioavailability of nimesulide was $89.42 \%$ after i.m administration. These pharmacokinetic data suggests that nimesulide given intramuscularly may be useful in the treatment of inflammatory disease conditions in bovines.
\end{abstract}

\section{Introduction}

Nimesulide (4-nitro-2-phenoxymethanesulfonanilide) is a nonsteroidal anti-inflammatory drug (NSAID) belonging to the sulphonanilide class, and is the first COX-2 preferential inhibitor to be marketed worldwide (Bennett and Villa, 2000). Nimesulide, has been used in humans for primary treatment of patients who need a rapid anti-inflammatory and analgesic action and the drug is among the most prescribed NSAIDs worldwide (Bennett, 1999; Bennett and Villa, 2000; Rainsford, 2006). Unlike most traditional NSAIDs that inhibit both cyclooxygenase COX-1 and COX-2 isoforms, nimesulide selectively blocks COX-2 which is induced in inflammatory conditions (Rainsford, 1999; Rainsford, 2006). Nimesulide has got potent anti-inflammatory activity and the therapy with enrofloxacin and nimesulide was found more efficacious $(92.30 \%)$ in treating subclinical mastitis in cows (Joshi and Gokhale, 2006). The simultaneous inhibition of COX-1 by the traditional NSAIDs largely accounts for gastrointestinal damage and alterations in the homeostasis functions of the prostanoids preferentially synthesized by this isozyme (Raskin, 1999; Raskin, 2006). It has been demonstrated to cause less gastrointestinal side effects compared to classical NSAIDs and this better tolerability correlates to its preferential COX-2 inhibitory potency (Famaey, 1997; Bennett and Villa, 2000). The therapeutic effects of nimesulide are the result of its multifactorial mode of action, which targets a number of key mediators of the inflammatory process. The drug is considered to be a preferential inhibitor of cyclooxygenase-2 (COX-2), since it also exerts some degree of COX-1 inhibition (Panara et al., 1998) thus blocking the production of prostanoids, many of which are actively involved in the inflammatory process (Tavares et al., 1995). However, in addition to COX inhibition, nimesulide has other pharmacological effects which may contribute to its clinical efficacy in many inflammatory processes.

Pharmacokinetic aspects of nimesulide have been fully documented in human (Bernareggi, 1998) and some animal species. The therapeutic usefulness of nimesulide largely relates to its pharmacokinetic properties in the target species. The pharmacokinetic properties and in vitro potency of nimesulide were investigated in dogs (Toutain et al., 2001), in horses (Villa et al., 2003), in goats (Rao et al., 2007), in sheep (Malik et al., 2008) and more recently, in some companion animals. In bovines nimesulide is used in combination with antimicrobials for treatment of disease condition such as acute mastitis, pneumonia, viral and bacterial respiratory diseases. Pharmacokinetic data provides information about the half-life, bioavailability and elimination profile of the drug which gives an insight into the dosage regimen to be adopted in both normal and in diseased conditions. So pharmacokinetic data for those drugs is essential that are species specific e.g. NSAIDs. Several studies have emphasized that pharmacokinetic data of NSAIDs in different animals cannot be transposed to the bovines. Yet such data are essential

*Corresponding author: Subas Ch. Parija, Department of Pharmacology and Toxicology, College of Veterinary Sciences and Animal Husbandry, Orissa University of Agriculture and Technology, Bhubaneswar751003, E-mail:scp4691@yahoo.co.in

Received October 31, 2009; Accepted December 16, 2009; Published December 16, 2009

Citation: Mahapatra L, Sahoo GR, Panda MK, Parija S (2009) Pharmacokinetic Profile of Nimesulide in Bovine Calves. J Bioequiv Availab 1: 121-026. doi:10.4172/jbb.1000019

Copyright: ( $) 2009$ Mahapatra L, et al. This is an open-access article distributed under the terms of the Creative Commons Attribution License, which permits unrestricted use, distribution, and reproduction in any medium, provided the original author and source are credited. 


\section{Journal of Bioequivalence \& Bioavailability - Open Access \\ JBB/Vol.1 November-December 2009}

for rational and judicious use of this drug in bovine medicine. The present investigation was therefore undertaken with the ultimate objective to establish bioavailability and pharmacokinetic parameters of nimesulide following intravenous and intramuscular administration at $4.5 \mathrm{mg} / \mathrm{kg} \mathrm{BW}$ in bovine calves.

\section{Materials and Methods}

\section{Experimental animals}

The study was conducted in six clinically healthy male bovine calves of $6.25 \pm 0.45$ months-old weighing from 60 to $70 \mathrm{~kg}$. Body weight of each animal was recorded on the day prior to initiation of the experiment. The animals were fed concentrates, green fodder and roughage and had free access to water ad libitum. All the animals were acclimated for at least 7 days prior to the start of the study. This study was approved by the institutional Animal Ethics committee.

\section{Drug administration}

Nimesulide (Nimovet 10\%; Indian Immunologicals Ltd. Hyderabed, India) was administered intravenously or Intramuscularly at a dose of $4.5 \mathrm{mg} / \mathrm{kg} \mathrm{BW}$ as a single dose. In the I.V. study, the drug was injected into the jugular vein using intravenous cannula opposite to the one from which blood samples were collected. Blood samples were also collected by jugular venipuncture following i.m. administration of nimesulide. The study was conducted using two-way crossover design. The same six animals were used for all the studies i.e single intravenous (i.v) and single intramuscular (i.m) administration of the drug. The animals received the drug by i.m route first and then i.v route. A wash out period of three weeks was given between the two treatments.

\section{Sampling}

Blood samples were collected into heparinized tubes before drug administration and at 0.033, 0.083, 0.167, 0.25, 0.5, 0.75, $1,1.5,2,3,4,5,6,7,8,10,12,24,48$ and $72 \mathrm{~h}$ after i.v. or i.m. administration of nimesulide. Plasma was separated by centrifugation $\left(3700 \mathrm{~g}, 10 \mathrm{~min}\right.$ at $\left.-4^{\circ} \mathrm{C}\right)$ within $30 \mathrm{~min}$ of sample collection, and aliquot fractions were stored at $-20^{\circ} \mathrm{C}$ until assayed. Before analysis $1 \mathrm{ml}$ of Acetonitrile was added to $0.5 \mathrm{ml}$ of plasma in a test tube and mixed thoroughly by vertex mixer at high speed for $1 \mathrm{~min}$. The samples were centrifuged at 5000rpm for $10 \mathrm{~min}$. The supernatant was collected, filtered through $0.22 \mu \mathrm{m}$ nylon membrane filter.

\section{Nimesulide assay}

Analysis was carried out by HPTLC using CAMAG linomat 5 operated by WINCATS planar chromatography manager. Plasma samples were prepared using previously described method with little modification (Toutain et al., 2001). About $15 \mu$ l sample was taken in the Hamilton syringe for spraying on the TLC plate. The glass plates $(20 \times 10 \mathrm{~cm})$ precoated with silica gel $60 \mathrm{~F}_{254}$ (layer thickness $0.2 \mathrm{~mm}$ ) were used. Samples were sprayed onto the chromatographic layer from the tip of the syringe needle. The syringe volume was $100 \mu \mathrm{l}$. The gas used for spraying was nitrogen (60-90 psi). The sample was uniformly distributed over the entire length of the band by carefully controlling stage movement. The samples were streaked in form of narrow bands or spots of $6 \mathrm{~mm}$ with $10 \mathrm{~mm}$ from the bottom edge and $10 \mathrm{~mm}$ from the margins. The application volume was $8 \mu \mathrm{l}$. The distance be- tween the tracks was adjusted basing on the number of samples applied. The mobile phase used was a combination of cyclohexane and ethyl acetate $(60: 40, \mathrm{v} / \mathrm{v})$ basing on polarity of the analyte. The chromatogram was run upto $90 \mathrm{~mm}$. The plates were developed in CAMAG twin trough glass chamber $(20 \times 10 \mathrm{~cm})$ saturated with the mobile phase. The developed plates were air dried. The analysis was carried out in TLC Scanner3 in absorbance mode. The slit dimension was $6.00 \times 0.30 \mathrm{~mm}$ and detection wavelength was $220 \mathrm{~nm}$. Data resolution was $100 \mu \mathrm{m} / \mathrm{step}$. The source of radiation was deuterium lamp. The scanning speed was $20 \mathrm{~mm} /$ sec. The peak areas and Rf values were noted for subsequent calculations. Documentation was done in Camag Reprostar 3. Nimesulide was quantified from its peak height and the concentrations in plasma samples were determined by means of calibration curves obtained on analysis of blank bovine plasma samples spiked with nimesulide (external standard) and assayed as per the procedure employed for the experimental samples. The calibration curve constructed for nimesulide in bovine calf blood plasma was found to be linear over the range of 20-900ng/ spot. The lower limit of detection (LOD) and lower limit of quantification (LOQ) were found to be 6.64ng and 20.12ng, respectively. The overall recovery of the drug in bovine plasma ranges from $91.3 \%$ to $99.96 \%$.

\section{Pharmacokinetic analysis}

The individual plasma drug concentration-time profiles were analyzed using a nonlinear interactive curve-fitting computer program PHARMKIT (Sanyal, 1997). The appropriate pharmacokinetic model for each data set was determined by the application of the Akaike's Information Criterion (Yamaoka et al., 1978). In all animals, the disposition kinetics of nimesulide after i.v. and i.m. administration were best fitted by two- and onecompartment open models, respectively, and defined by the equations:

$$
\begin{aligned}
& \mathrm{Cp}=\mathrm{Ae}^{-\alpha \mathrm{t}}+\mathrm{Be}^{-\beta \mathrm{t}} \text { (i.v. stydy) } \\
& \mathrm{Cp}=\mathrm{Be}^{-\beta \mathrm{t}}-\mathrm{A}^{\prime} \mathrm{e}^{-\mathrm{kat}} \text { (i.m.stydy) }
\end{aligned}
$$

Where $\mathrm{Cp}$ is the plasma concentration of nimesulide at time $\mathrm{t}$, $\mathrm{A}, \mathrm{A}^{\prime}$ and $\mathrm{B}$ are the zero time intercepts, $\alpha, \mathrm{Ka}$ and $\beta$ are the first order rate constants related to the distribution, absorption and elimination phases, respectively, and e represents the base of natural logarithm.

The pharmacokinetic parameters of nimesulide were calculated according to Gibaldi and Perrier, (1982). The half-lives during the distribution $\left(\mathrm{t}_{1 / 2 \alpha}\right)$, absorption $\left(\mathrm{t}_{1 / 2 \mathrm{Ka}}\right)$ and terminal elimination $\left(\mathrm{t}_{1 / 2 \beta}\right)$ phases were calculated as follows:

$$
\begin{aligned}
& t_{1 / 2 \alpha}=\frac{0.693}{\alpha} \\
& t_{1 / 2 K a}=\frac{0.693}{k a} \\
& t_{1 / 2 \beta}=\frac{0.693}{\beta}
\end{aligned}
$$

The apparent volume of distribution $\left(\mathrm{V}_{\mathrm{d}(\text { area })}\right)$, steady- state volume of distribution $\left(\mathrm{V}_{\mathrm{d}(\mathrm{ss})}\right)$ and total body clearance $\left(\mathrm{Cl}_{\mathrm{B}}\right)$ of nimesulide following i.v, administration were calculated accord- 


\section{Journal of Bioequivalence \& Bioavailability - Open Access}

JBB/Vol.1 November-December 2009

ing to the following equations:

$$
\begin{aligned}
& V d(\text { area })=\frac{D}{\beta}(A U C) \\
& C l_{B}=\frac{D}{(A U C)}
\end{aligned}
$$

Where $\mathrm{D}$ is the dose of the drug.

The mean absorption time (MAT), mean residence time (MRT) and bioavailability (F) were calculated using the following formulate:

$$
\begin{aligned}
& \text { MAT }=\mathrm{MRT}_{\mathrm{i} . \mathrm{m}}-\mathrm{MRT}_{\mathrm{i} . \mathrm{v}} \\
& M R T=\frac{A U M C}{A U C} \\
& F=\frac{A U C_{i m}}{A U C_{i v}} \times 100
\end{aligned}
$$

The area under the plasma concentration-time curve (AUC) and area under the first moment curve (AUMC) were calculated according to the following

$$
\begin{aligned}
& A U C=\frac{A}{\alpha}+\frac{B}{\beta} \text { (i.v. study) } \\
& A U C=\frac{B}{\beta}-\frac{A^{\prime}}{K_{a}}(\text { i.m. study) } \\
& A U M C=\frac{A}{\alpha^{2}}+\frac{B}{\beta^{2}}(\text { i.v. study) } \\
& A U M C=\frac{B}{\beta^{2}}-\frac{A^{\prime}}{K a^{2}}(i . m . \text { study) }
\end{aligned}
$$

\begin{tabular}{|c|c|c|c|}
\hline \multirow{2}{*}{$\begin{array}{l}\text { Kinetic } \\
\text { Parameters }\end{array}$} & \multirow{2}{*}{ Units } & \multicolumn{2}{|l|}{$\begin{array}{l}\text { Route of } \\
\text { administration }\end{array}$} \\
\hline & & i.v. & i.m. \\
\hline A & $\mu \mathrm{g} / \mathrm{ml}$ & $88.87 \pm 9.82$ & \\
\hline$A^{\prime}$ & $\mu \mathrm{g} / \mathrm{ml}$ & & $482.74 \pm 30.07$ \\
\hline B & $\mu \mathrm{g} / \mathrm{ml}$ & $16.54 \pm 1.62$ & $2.97 \pm 0.18$ \\
\hline A & h-1 & $4.74 \pm 0.20$ & \\
\hline $\mathrm{Ka}$ & h-1 & & $0.84 \pm 0.02$ \\
\hline B & h-1 & $0.08 \pm 0.0005$ & $0.04 \pm 0.001$ \\
\hline $\mathrm{T}_{1 / 2 \alpha}$ & $\mathrm{h}$ & $0.15 \pm 0.005$ & \\
\hline $\mathrm{T}_{1 / 2 \mathrm{ka}}$ & $\mathrm{h}$ & & $0.85 \pm 0.008$ \\
\hline $\mathrm{T}_{1 / 2 \mathrm{~B}}$ & $\mathrm{~h}$ & $9.02 \pm 0.06$ & $20.08 \pm 0.79 * * *$ \\
\hline AUC & $\mu \mathrm{g} . \mathrm{h} / \mathrm{ml}$ & $229.54 \pm 23.24$ & $204.71 \pm 13.90$ \\
\hline AUMC & $\mu \mathrm{g} . \mathrm{h} 2 / \mathrm{ml}$ & $2577.18 \pm 264.14$ & $2817.90 \pm 205.37$ \\
\hline MRT & $\mathrm{h}$ & $11.23 \pm 0.04$ & $13.76 \pm 0.09 * *$ \\
\hline $\mathrm{Vd}($ area $)$ & $\mathrm{L} / \mathrm{kg}$ & $0.26 \pm 0.02$ & \\
\hline $\mathrm{Vd}(\mathrm{ss})$ & $\mathrm{L} / \mathrm{kg}$ & $0.22 \pm 0.02$ & \\
\hline $\mathrm{Clb}$ & $\mathrm{L} / \mathrm{h} / \mathrm{kg}$ & $0.02 \pm 0.001$ & \\
\hline $\mathrm{C}_{\max }$ & $\mu \mathrm{g} / \mathrm{ml}$ & & $35.48 \pm 3.04$ \\
\hline $\mathrm{t}_{\max }$ & $\mathrm{h}$ & & $4.0 \pm 0.19$ \\
\hline MAT & $\mathrm{h}$ & & $0.89 \pm 0.04$ \\
\hline $\mathrm{F}$ & $\%$ & & $89.42 \pm 3.57$ \\
\hline
\end{tabular}

The maximum plama nimesulide concentration $\left(\mathrm{C}_{\max }\right)$ and the

\begin{tabular}{|c|c|c|}
\hline $\begin{array}{c}\text { Time after drug } \\
\text { administration } \\
(\mathbf{h})\end{array}$ & i.v. & i.m. \\
\hline 0.033 & $107.06 \pm 8.37$ & $4.88 \pm 1.02$ \\
\hline 0.083 & $102.02 \pm 10.69$ & $5.86 \pm 0.90$ \\
\hline 0.167 & $39.87 \pm 7.99$ & $8.007 \pm 0.56$ \\
\hline 0.25 & $39.82 \pm 7.03$ & $7.18 \pm 0.62$ \\
\hline 0.5 & $26.16 \pm 2.10$ & $9.23 \pm 0.57$ \\
\hline 1 & $20.37 \pm 2.04$ & $11.07 \pm 0.79$ \\
\hline 1.5 & $17.73 \pm 1.89$ & $16.79 \pm 1.44$ \\
\hline 2 & $16.52 \pm 1.24$ & $21.98 \pm 1.90$ \\
\hline 3 & $14.96 \pm 1.55$ & $30.20 \pm 2.59$ \\
\hline 4 & $12.65 \pm 1.68$ & $35.48 \pm 3.04$ \\
\hline 6 & $9.37 \pm 0.86$ & $11.22 \pm 0.96$ \\
\hline 8 & $7.33 \pm 0.66$ & $5.37 \pm 0.46$ \\
\hline 10 & $6.15 \pm 0.72$ & $2.04 \pm 0.18$ \\
\hline 12 & $4.94 \pm 0.77$ & $1.29 \pm 0.21$ \\
\hline 24 & $2.10 \pm 0.19$ & $0.76 \pm 0.10$ \\
\hline 48 & $0.53 \pm 0.05$ & $0.47 \pm 0.12$ \\
\hline 72 & $\mathrm{ND}$ & $0.31 \pm 0.03$ \\
\hline
\end{tabular}

Table 1: Mean \pm SD plasma nimesulide concentration $(\mu \mathrm{g} / \mathrm{ml}$. following i.v. and i.m.administration of $4.5 \mathrm{mg} / \mathrm{kg} \mathrm{BW}$ in bovines $(\mathrm{n}=6)$.
Table 2: Mean \pm SD of the pharmacokinetic parameters of nimesulide following i.v. and i.m.administration of $4.5 \mathrm{mg} / \mathrm{kg} \mathrm{BW}$ in bovines $(\mathrm{n}=6)$.

time to reach the maximum plama concentration $\left(\mathrm{t}_{\max }\right)$ were determined from the individual plasma concentration-time profiles.

\section{Statistical analysis}

Results are presented as mean \pm SD for the six calves. Harmonic means and pseudostandard deviations were calculated for the half-lives during the distribution, absorption and terminal elimination phases (Lam et al., 1985). Differences between respective mean values for half-life during the terminal elimination phase, AUC and MRT for the i.v and i.m, routes of administration were compared by unpaired t-test with Welch correction. All P-values $<0.05$ were considered statistically significant.

\section{Results}

The mean plasma concentration of nimesulide at specified time after single i.v. injection at a dose of $4.5 \mathrm{mg} / \mathrm{kg}$ body has been presented in Table 1 . The mean maximum plasma concentration $(107.06 \pm 8.37 \mu \mathrm{g} / \mathrm{ml}, \mathrm{n}=6)$ was observed at $2 \mathrm{~min}(0.033 \mathrm{~h})$ and then reduced rapidly upto $1.5 \mathrm{hr}(17.73 \pm 1.89 \mu \mathrm{g} / \mathrm{ml}, \mathrm{n}=6)$ and thereafter, the drug concentration in plasma declined gradually till it reached its mean minimum level of $0.53 \pm 0.05 \mu \mathrm{g} / \mathrm{ml}(\mathrm{n}=6)$ at $48 \mathrm{~h}$ post administration. The concentration of nimesulide was not detected at $72 \mathrm{hr}$ interval. Table 2 summerizes the mean pharmacokinetic parameters following i.v. administration. The semi- 


\section{Journal of Bioequivalence \& Bioavailability - Open Access \\ JBB/Vol.1 November-December 2009}

logarithmic plot of the observed and fitted plasma concentration of nimesulide vs time (h) after i.v. administration is shown as mean value for six representative bovine calves. The plasma concentration-time curve was best fitted to two compartment open model (Figure 1). The drug was rapidly distributed with $\mathrm{t}_{1 /}$ ${ }_{2 \alpha}$ of $0.15 \pm 0.005 \mathrm{~h}$ and slowly eliminated with $\mathrm{t}_{1 / 2 \beta}$ of $9.02 \pm 0.06$ $\mathrm{h}$. The apparent volume of distribution based on AUC $\left(\mathrm{V}_{\mathrm{d}(\text { area }}\right)$, $\mathrm{V}_{\mathrm{d}(\mathrm{ss})}$ and MRT were $0.26 \pm 0.02 \mathrm{~L} / \mathrm{kg}, 0.22 \pm 0.02 \mathrm{~L} / \mathrm{kg}$ and $11.23 \pm 0.04 \mathrm{~h}$, respectively. The total body clearance was $0.02 \pm 0.001 \mathrm{~L} / \mathrm{h} / \mathrm{kg}$.

The mean plasma concentration of nimesulide at specified time after single i.m. injection at a dose of $4.5 \mathrm{mg} / \mathrm{kgBW}$ has been presented in Table 1. The mean maximum plasma concentration $(35.48 \pm 3.04 \mu \mathrm{g} / \mathrm{ml}, \mathrm{n}=6)$ was observed at $4.0 \pm 0.19 \mathrm{~h}$ and then reduced rapidly upto $8 \mathrm{~h}$ to a concentration $5.37 \pm 0.46 \mu \mathrm{g} / \mathrm{ml}(\mathrm{n}=6)$ and thereafter, the drug concentration in plasma declined gradually till it reached its mean minimum level of $0.31 \pm 0.03 \mu \mathrm{g} / \mathrm{ml}$ $(\mathrm{n}=6)$ at $72 \mathrm{hr}$ post administration. The semilogarithmic plot of the observed and fitted plasma concentration $(\mu \mathrm{g} / \mathrm{ml})$ of nimesulide vs time (h) after i.m.. administration is shown as mean value for six representative bovine calves. The plasma concentration-time curve was best fitted to one compartment open model (Figure 1). After the i.m. administration, the absorption of nimesulide was rapid as indicated by the mean absorption time (MAT) of $0.89 \pm 0.04 \mathrm{~h}(\mathrm{n}=6)$. The MRT, which takes into account the absorption, distribution and elimination phases was $13.76 \pm 0.09 \mathrm{~h}$ indicating that nimesulide persists for a long time in the bovine plasma after i.m. administration. The $t_{1 / 2 \beta}$ $(20.08 \pm 0.79 \mathrm{~h})$ was significantly higher $(\mathrm{p}<0.001)$ than that was collected after the i.v. administration. The mean bioavailability of nimesulide was $89.42 \pm 3.57 \%$. Similarly, the MRT was significantly longer $(\mathrm{p}<0.005)$ than that obtained after i.v. administration (Table 2).

\section{Discussion}

The disposition kinetics of nimesulide after i.v. dose of 4.5

\section{CONCENTRATION VS TIME PLOT OF NIMESULIDE AFTER IV AND IM} ADMINISTRATION

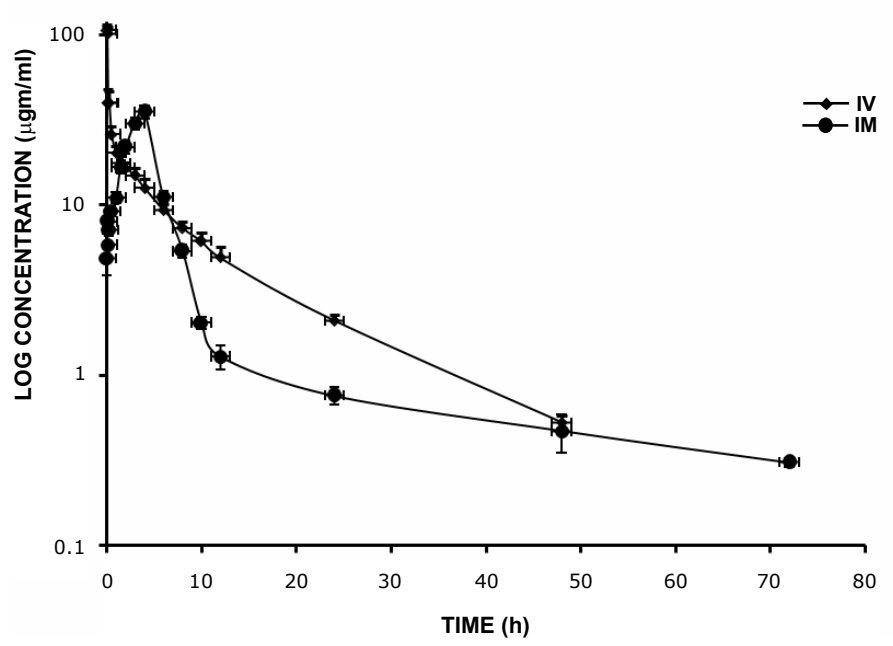

Figure 1: Semilogarithmic plot of the mean plasma nimesulide concentration-time profile following i.v and i.m. administration of nimesulide @ 4.5mg/ $\mathrm{kg} \mathrm{BW}$. After administration of nimesulide blood samples were collected at 0.033h, 0.083h, 0.167h, 0.25h, 0.5h, 1h, 1.5h, 2h, 3h, 4h, 6h, 8h,10h,12h, 24h, $48 \mathrm{~h}$ and $72 \mathrm{~h}$ both in iv and im route of administration. $\mathrm{mg} / \mathrm{kg} \mathrm{BW}$ was best fitted by a two-compartment open model. A biexponential plasma concentration-time profile has also been previously reported in dogs given nimesulide @ $5 \mathrm{mg} / \mathrm{kg}$ intravenously (Toutain et al., 2001) and in goats given $4 \mathrm{mg} / \mathrm{kg}$ i.v. (Rao et al., 2007). The half-life during the terminal elimination phase $(9.02 \pm 0.06 \mathrm{~h})$ of nimesulide in bovines is higher than dogs (8.5 $\pm 2.1 \mathrm{~h}$; Toutain et al., 2001), goats $(7.99 \pm 2.23 \mathrm{~h}$; Rao et al., 2007) and in sheep (7.11 $\pm 0.83 \mathrm{~h}$; Malik et al., 2008). The mean residence time $(11.23 \pm 0.04 \mathrm{~h})$ of nimesulide in bovines is lower than dogs (12.6 $\pm 3.8 \mathrm{~h}$; Toutain et al., 2001), goats $(11.72 \pm 3.42 \mathrm{~h}$; Rao et al.,2007) and higher than sheep $(8.73 \pm 1.00 \mathrm{~h}$; Malik et al., 2008). Relatively shorter $\mathrm{t}_{1 / 2 \beta}$ of $6.13 \mathrm{~h}$ and MRT of $8.63 \mathrm{~h}$ of nimesulide were reported in horses after i.v. administration of nimesulide at $1.5 \mathrm{mg} / \mathrm{kg} \mathrm{BW}$ (Villa et al., 2003). The variable half-lives encountered in different species may be due to difference in protein binding capacity of the drug in different species. The value of $\mathrm{Vd}_{\text {(ss) }}$ of $(0.22 \pm 0.02 \mathrm{~L} / \mathrm{kg})$ in bovines is lower than that in goats $(0.64 \pm 0.13 \mathrm{~L} / \mathrm{kg}$; Rao et al., 2007), in sheep $(0.53 \pm 0.07 \mathrm{~L} / \mathrm{kg}$; Malik et al., 2008) and is higher than that in dogs $(0.18 \mathrm{~L} / \mathrm{kg}$ : Toutain et al., 2001a), in horses $(0.117 \mathrm{~L} / \mathrm{kg}$; Villa et al., 2003) and in humans $(0.18-0.39 \mathrm{~L} / \mathrm{kg}$; Bernareggi, 1998). Small volume of distribution of nimesulide in most of the species is similar to most NSAIDs, as they are highly bound to plasma proteins. High values of $\mathrm{Vd}$ have also been reported for other NSAIDs including flunixin in cows $(1.05 \mathrm{~L} / \mathrm{kg}$; Hardee et al., 1985), tolfenamic acid in calves (1.79-3.2 L/kg: Lees et al., 1998 ) and celecoxib in humans (4.5 L/kg; Davies et al., 2000). Highly lipophilic drugs are characterized by a large volume distribution. The large Vd may also be due to altered and highaffinity tissue binding properties (Riviere, 1999). Celecoxib and nimesulide are known to posses high lipophilicity (Seedher and Bhatia, 2003). In bovines the $\mathrm{Cl}_{\mathrm{B}}$ was $0.02 \pm 0.001 \mathrm{~L} / \mathrm{h} / \mathrm{kg}$ lower than in goats $(0.06 \pm 0.02 \mathrm{~L} / \mathrm{h} / \mathrm{kg})$ and almost similar in dogs $(0.015 \pm 0.004 \mathrm{~L} / \mathrm{h} / \mathrm{kg})$.

Although i.v. is not the most likely route of administration of nimesulide in goats, i.v. pharmacokinetic study was performed to establish disposition kinetic variables, such as $\mathrm{Vd}_{(\text {area) }}, \mathrm{Vd}_{(\mathrm{ss})}$ and $\mathrm{Cl}_{\mathrm{B}}$, which could only be obtained after i.v. administration. The values of area under the plasma concentration-time curves obtained after i.v. injection were employed for determination of bioavailability of nimesulide following i.m. administration. Intramuscular administration of nimesulide to bovines at a dose of $4.5 \mathrm{mg} / \mathrm{kg}$ BW was associated with rapid appearance of the drug in plasma. Plasma drug concentrations after i.m. injection were more prolonged than after i.v. administration. The maximum plasma drug concentration $\left(\mathrm{C}_{\max }\right)$ of $35.48 \pm 3.04 \mu \mathrm{g} / \mathrm{mL}$ was observed at $4 \mathrm{~h}$ post administration in bovines. A Cmax of $6.1 \pm 1.5$ $\mu \mathrm{g} / \mathrm{mL}$ was observed at $10.9 \mathrm{~h}$ in dogs given nimesulide at $5 \mathrm{mg} /$ $\mathrm{kg}$ intramuscularly (Toutain et al., 2001). In goats and sheeps, the $\mathrm{C}_{\max }$ values were reported to be $(2.83+1.11 \mu \mathrm{g} / \mathrm{mL})$ at $3.6 \mathrm{~h}$ (Rao et al., 2007) and $8.65 \pm 1.09 \mu \mathrm{g} / \mathrm{mL}$ at $2 \mathrm{~h}$ (Telang et al., 2008) given nimesulide @ 4mg/kg BW intramuscularly. Higher value of $\mathrm{C}_{\max }$ was reported in horses even after oral administration of nimesulide at a dose much lower than that used in the present study. $\mathrm{A} \mathrm{C}_{\max }$ of $3.94 \mu \mathrm{g} / \mathrm{mL}$ at $3.5 \mathrm{~h}$ was reported in horses given nimesulide orally at $1.5 \mathrm{mg} / \mathrm{kg}$ (Villa et al., 2003). The value of AUC after i.m. administration of nimesulide in bovines $(204.71 \pm 13.90 \mu \mathrm{g} . \mathrm{h} / \mathrm{mL})$ was 4.3 fold higher than in goats $(47.22 \pm 14.01 \mu \mathrm{g} . \mathrm{h} / \mathrm{mL})$ at a dose of $4 \mathrm{mg} / \mathrm{kgBW}$ i.m. In dogs AUC was reported to be $(228 \pm 54 \mu \mathrm{g} . \mathrm{h} / \mathrm{ml})$ given the drug 


\section{Journal of Bioequivalence \& Bioavailability - Open Access \\ JBB/Vol.1 November-December 2009}

at $5 \mathrm{mg} / \mathrm{kg}$ intramuscularly (Toutain et al., 2001). The $\mathrm{t}_{1 / 2 \beta}$ value after i.m. injection in bovines is $20.08 \pm 0.79 \mathrm{~h}$ is higher than that in goats $(13.03 \pm 1.71 \mathrm{~h})$, in sheep $(6.27 \pm 0.30 \mathrm{~h})$ and in dogs $(14.0 \pm 5.30 \mathrm{~h})$. The higher values of $\mathrm{t}_{1 / 2 \beta}$ and AUC in bovines are indicative of higher bioavailability of the drug. The systemic clearance in bovines $(0.02 \pm 0.001 \mathrm{~L} / \mathrm{h} / \mathrm{kg})$ is similar to that in dogs and about one third of the systemic clearance in goats and in sheeps. Lower clearance in bovines is indicative of longer stay of the drug in the body.

The route of administration appears to influence the $t_{1 / 2 \beta}$ and MRT of nimesulide. In the present study $t_{1 / 2 \beta}$ and MRT of nimesulide after i.m. administration were $20.08 \pm 0.79 \mathrm{~h}$ and $13.76 \pm 0.09 \mathrm{~h}$ were 2.22 and 1.22 times longer, respectively, than the i.v. administration. In goats the $t_{1 / 2 \beta}$ and MRT of nimesulide after i.m. administration were 1.63 and 1.73 times longer respectively than the i.v. route. Markedly longer $\mathrm{t}_{1 / 2 \beta}$ (1.6 times) and MRT (2.3 times) after i.m. injection of nimesulide when compared with i.v. administration were also reported in dogs (Toutain et al., 2001). The MAT of $0.89 \pm 0.04 \mathrm{~h}$ was obtained following i.m. administration of nimesulide in bovines was shorter than that reported in dogs $(17.6 \mathrm{~h})$, receiving the drug intramuscularly at $5 \mathrm{mg} / \mathrm{kg}$ (Toutain et al., 2001) and in goats $(8.5 \mathrm{~h}) \mathrm{re}-$ ceiving $4 \mathrm{mg} / \mathrm{kg} \mathrm{BW}$ (Rao et al., 2007). This indicates that longer bioavailability of the drug is not due to decreased elimination but due to increased absorption. It is known that the disposition kinetics of certain drugs administered by extravascular route may exhibit 'flip-flop' phenomenon. Nimesulide administred intramuscularly was shown to follow a 'flip-flop' model in dogs (Toutain et al., 2001). This occurs when the value of elimination rate constant $(\beta)$ divided by the absorption rate constant $(\mathrm{ka})$ exceeds 3 and resultantly, the terminal slope estimates ka and feathered line $\beta$ (Notari, 1987). Although terminal half-life of nimesulide was markedly prolonged following i.m. administration in this study, $\beta / \mathrm{ka}$ value of nimesulide after i.m. administration of $4.5 \mathrm{mg} / \mathrm{kg}$ was 0.04 suggesting lack of occurrence of the above phenomenon. The systemic availability of nimesulide in bovines after i.m. administration of $4.5 \mathrm{mg} / \mathrm{kg}$ was $89.42 \pm 3.57 \%$ while in goats $68 \%$ (Rao et al., 2007), 69\% in dogs (Toutain et al., 2001). To the authors' knowledge, absolute bioavailability of nimesulide has not been determined in humans as no i.v. pharmacokinetic data of this drug are available.

Although both COX isoforms are involved in synthesis of prostanoids, COX-1 is constitutively expressed in nearly all cell types while COX-2, which is also constitutive in many tissues, is induced in inflammatory conditions. NSAIDs such as nimesulide that selectively inhibit COX-2 may not affect physiological functions of the prostanoids preferentially synthesized by COX-1 and COX1 inhibition-associated gastrointestinal damage. The present study determined that maximum plasma nimesulide concentration after an i.m. dose of $4.5 \mathrm{mg} / \mathrm{kgBW}$ in bovines is $35.48 \pm 3.04 \mu \mathrm{g} / \mathrm{mL}$ and that at $24 \mathrm{~h}$ is $0.76+0.10 \mu \mathrm{g} / \mathrm{mL}$. The COX inhibitory activity of nimesulide may be instructive of approximating its effective plasma drug concentration, although direct evaluations between in vitro and in vivo findings must be made with caution. Previous studies have emphasized difficulty in comparing data between species as the drugs that are highly selective COX-2 inhibitors in one species may not necessarily exert the same selectively in other species (Pairet and van Ryn, 1998; Brideau et al., 2001).
This is the first report of the pharmacokinetics and bioavailability of nimesulide in bovines. Our findings suggests that there appear to be major differences between the pharmacokinetic properties of nimesulide in bovines and other species. The kinetic data established in this study provide highly useful information and suggest that nimesulide administered by i.m. route may be useful in the treatment of inflammatory disease conditions in bovines. Further studies are needed to determine the efficacy and safety of nimesulide in bovines with various inflammatory disease conditions.

\section{References}

1. Bennet (1999) Overview of Nimesulide. Rheumatology 38: 13. »CrossRef » Pubmed » Google Scholar

2. Bennett A, Villa G (2000) Nimesulide: an NSAID that preferentially inhibits COX-2, and has various unique pharmacological activities. Exp Opin Pharmacother 1: 277-86. »CrossRef » Pubmed » Google Scholar

3. Bernareggi A (1998) Clinical Pharmacokinetics of Nimesulide. Clin Pharmacokinet 35: 247-274. »CrossRef » Pubmed » Google Scholar

4. Brideau C, Van Staden C, Chan CC (2001) In vitro effect of cyclooxygenase inhibitors in whole blood of horses, dogs and cats. Am J Vet Res 62: 1755-1760. »CrossRef» Pubmed» Google Scholar

5. Burke A, Smyth EM, FitzGerald GA (2006) Analgesics and antipyretic agents: pharmacotherapy of gout. In Goodman \& Gilman's The Pharmacological Basis of Therapeutics pp671715. » CrossRef » Pubmed » Google Scholar

6. Davies NM, Skjodt NM (2000) Choosing the right nonsteroidal anti-inflammatory drug for the right patient: a pharmacokinetic approach. Clin Pharmacokinet 38: 377-92. »CrossRef » Pubmed » Google Scholar

7. Famaey JP (1997) In vitro and in vivo pharmacological evidence of selective cyclooxygenase- 2 inhibition by nimesulide: an overview. Inflamm Res 46: 437-446. » CrossRef » Pubmed » Google Scholar

8. Gibaldi M, Perrier D (1982) One-compartment model. In Pharmacokinetics. Ed Swarbrick J pp1-43. »CrossRef» Pubmed » Google Scholar

9. Hardee GE, Smith JA, Harris SJ (1985) Pharmacokinetics of flunixin meglumine in the cow. Res Vet Sci 39: 110-112. »CrossRef » Pubmed » Google Scholar

10. Joshi S, Gokhale S (2006) Status of mastitis as an emerging disease in improved and periurban dairy farms in India. Ann N Y Acad Sci 1081: 74-83. » CrossRef » Pubmed » Google Scholar

11. Lam FC, Hung CT, Perrier DG (1985) Estimation of variance for harmonic mean half-lives. J Pharm Sci 74: 229231. » CrossRef » Pubmed » Google Scholar

12. Lees P, McKellar QA, Foot R, Gettinby G (1998) Pharmacodynam,ics and pharmacokinetics of tolfenamic acid in ruminating calves. Evaluation in models of acute inflammation. Vet J 155: 275-288. » CrossRef » Pubmed » Google Scholar

13. Malik et al. (2008) Nimesulide pharmacokinetics after intravenous administration in sheep. Paper presented in VIII An- 


\section{Journal of Bioequivalence \& Bioavailability - Open Access \\ JBB/Vol.1 November-December 2009}

nual Conference of ISVPT and National Symposium on Medicinal Plants and Wildlife. meglumine in the cow. Res Vet Sci 39: 110-112. »CrossRef » Pubmed » Google Scholar

14. Notari (1987) Biopharmaceutics and clinical pharmacokinetics-: An Introduction Marcel Dekker. New York 148: 221271. » CrossRef » Pubmed » Google Scholar

15. Pairet M, van Ryn J (1998) Experimental model used to investigate the differential inhibition of cyclooxygenase -1 and cyclooxygenase- 2 by non steroidal anti -inflammatory drugs. Inflamm Res 47: S93-S101. »CrossRef » Pubmed » Google Scholar

16. Panara MR, Padovano R, Sciulli MG, Santini G, Renda G, et al. (1998) Effects of nimesulide on constitutive and inducible prostanoid biosynthesis in human beings. Clin Pharmacol Ther 63: 672-81. »CrossRef » Pubmed » Google Scholar

17. Rainsford KD (1999) Relationship of nimesulide safety to its pharmacokinetics:assessment of adverse reactions. Rheumatology 38: 4-10. »CrossRef » Pubmed » Google Scholar

18. Rainsford KD (2006) Current status of the therapeutic uses and actions of the preferential cyclo-oxygenase-2 NSAID, nimesulide. Inflammopharmacology 14: 120-37. »CrossRef » Pubmed » Google Scholar

19. Rao GS, Malik JK, Siddaraju VB, Shankaramurthy NC (2007) Pharmacokinetics and bioavailability of Nimesulide in Goats. J vet Pharmacol Therap 30: 157-162. » CrossRef » Pubmed » Google Scholar

20. Raskin JB, White RH, Jackson JE (1999) Gastrointestinal effects of nonsteroidal anti-inflammatory. N Engl J Med 340: 1888-1899. » CrossRef » Pubmed » Google Scholar

21. Riviere JE (1999) Comparative Pharmacokinetics - Prin- ciples, Techniques, and Applications. Iowa State University Press, Ames. » CrossRef » Pubmed » Google Scholar

22. Sanyal PK (1997) Disposition kinetics of albendazole in buffalo and cattle. J Vet Pharmacol Ther 20: 240-242.

»CrossRef » Pubmed » Google Scholar

23. Seedher N, Bhatia S (2003) Solubility enhancement of COX2 inhibitors using various solvent systems. AAPS PharmSciTech 4: E33. » CrossRef » Pubmed » Google Scholar

24. Tavares IA, Bishai PM, Bennett A (1995) Activity of nimesulide on constitutive and inducible cyclooxygenases. Arzneimittelforschung 45: 1093-1095. » CrossRef » Pubmed » Google Scholar

25. Telang, et al. (2008) Plasma disposition kinetics and bioavailability of nimesulide after intramuscular administration in sheep (2008) Paper presented in VIII Annual Conference of ISVPT and National Symposium on Medicinal Plants and Wildlife.therapy. Am J Med 106: 3s-12s. » CrossRef » Pubmed » Google Scholar

26. Toutain PL, Cester CC, Haak T, Metge S (2001) Pharmacokinetic profile and in vitro selective cyclooxygenase- 2 inhibition by nimesulide in the dog. J Vet Pharmacol Therap 24: 35-42. » CrossRef » Pubmed » Google Scholar

27. Villa, et al. (2003) Pharmacokinetics of nimesulide in the horse. J Vet Pharmacol Ther 26: 107. » CrossRef » Pubmed » Google Scholar

28. Yamaoka K, Nakagawa T, Uno T (1978) Application of Akaike's Information Criterion (AIC) in the evaluation of linear pharmacokinetic equations. J Pharmacokinet Biopharm 6: 165-175. » CrossRef » Pubmed » Google Scholar 